\title{
Relatedness and polyandry of sixgill sharks, Hexanchus griseus, in an urban estuary
}

\author{
Shawn Larson · Jeff Christiansen • Denise Griffing • \\ Jimiane Ashe $\cdot$ Dayv Lowry $\cdot$ Kelly Andrews
}

Received: 28 June 2010/Accepted: 8 December 2010/Published online: 31 December 2010

(C) The Author(s) 2010. This article is published with open access at Springerlink.com

\begin{abstract}
The bluntnose sixgill shark (Hexanchus griseus) is a widely distributed species found in tropical and temperate waters of every ocean, yet we know relatively little about their basic biology including their life history and population structure. From 2003-2007, we collected over 300 biopsy samples from sixgills during research operations in Puget Sound, WA, USA. Genotypic data using ten polymorphic microsatellites were used to describe sixgill genetic diversity, relatedness and mating pattern. Diversity within sixgills was found to be moderate with an average observed heterozygosity of 0.45 , an average expected heterozygosity of 0.61 , an average of 12 alleles per locus, and an average allelic richness of eight within microsatellite loci. Our data suggests all of the sampled individuals come from one intermixing population, and we found no historical evidence of significant population bottlenecks. Many of the sharks were sampled using longline techniques with several sharks captured at the same time and place. Similarly, multiple sharks were sampled on several occasions during research events at the Seattle Aquarium. The proportion of individuals that were full- or half-siblings was high among sharks sampled at the same time and place (range 0.65-0.87). Analysis of the
\end{abstract}

S. Larson $(\bowtie) \cdot$ J. Christiansen · D. Griffing · J. Ashe

Seattle Aquarium, 1483 Alaskan Way, Pier 59, Seattle, WA 98101-2059, USA

e-mail: s.larson@seattleaquarium.org

D. Lowry

Washington Department of Fish and Wildlife, 1111 Washington

Street SE, Olympia, WA 98501, USA

K. Andrews

NOAA Fisheries, Northwest Fisheries Science Center, 2725

Montlake Boulevard East, Seattle, WA 98112, USA genetic relationship between one large female washed ashore and 71 of her near-term pups suggested a polyandrous mating system with as many as nine males contributing to her offspring. This study is the first to investigate genetic diversity, relatedness and paternity within sixgill sharks and sheds light on important conservation implications for this little known shark population.

Keywords Bluntnose sixgill - Hexanchus griseus . Microsatellites · Relatedness · Polyandry $\cdot$ Shark

\section{Introduction}

Sharks are found in every ocean of the world and are typically at the top of the food web in these systems. Many sharks mature slowly, have long developmental periods, and have low reproductive rates, making them vulnerable to exploitation by humans (Hoenig and Gruber 1990; Musick et al. 2000; Schindler et al. 2002; Baum et al. 2003; Baum and Myers 2004). Of the approximately 500 known shark species, the International Union for Conservation of Nature lists the status of $63 \%$ as near-threatened or worse ( 25 critically endangered, 42 endangered, 114 vulnerable, 134 near threatened, IUCN red list 2008). Effective management of most shark species has proven difficult because little is known about their basic biology and ecology.

In the summer of 2000, worldwide concern over the effects of commercial and recreational fishing on shark populations was brought to the forefront of public attention in Seattle, WA. Several bluntnose sixgill sharks, Hexanchus griseus, that had been observed and photographed often by recreational SCUBA divers were caught in the shallow waters of Elliott Bay off local fishing piers. Based on public outcry over the disappearance of the local 
sixgills, Washington State Department of Fish and Wildlife (WDFW) resource managers took precautionary action in 2003 by placing a temporary closure on the taking of sixgills in Puget Sound. They also initiated a scientific research program with partners from the Seattle Aquarium (SA) and the National Oceanographic and Atmospheric Association (NOAA) Fisheries Service to elucidate the basic biology and ecology of this poorly studied species.

Many observations of sixgill sharks have been made by fishers and biologists around the world but little is known about their behavior, life history, and ecological role. Sixgill sharks are often described as morphologically "primitive" in nature based on the presence of six gill openings and strongly dimorphic top and bottom teeth (Ellis 1983), attributes which are shared with several extinct species. Sixgills are one of the largest extant predatory sharks, with specimens up to $5 \mathrm{~m}$ and $500 \mathrm{~kg}$ (Castro 1983). They are viviparous and produce litters of 47-108 pups (Castro 1983). Males appear to mature at about $3.1 \mathrm{~m}$ and females at about $4.2 \mathrm{~m}$ (Ebert 2002, 2003).

Sixgills are one of the most widely distributed of all sharks, being found in every ocean in tropical and temperate waters. They are thought to be benthic and are generally found in deep water (Castro 1983). However, they have been observed in relatively shallow waters (less than $20 \mathrm{~m}$ ) in Puget Sound, WA and British Columbia (Castro 1983; Rupp 2001; Dunbrack and Zielinski 2003; Andrews et al. 2009), and have been caught in water as shallow as $30 \mathrm{~m}$ in the Mediterranean Sea (Capapé et al. 2004). Acoustic monitoring data suggest that sixgill sharks inhabit Puget Sound waters for several years as juveniles, making small seasonal migrations between a couple core areas before leaving Puget Sound for the open coast (Andrews et al. 2010). Sixgills within Puget Sound display diel vertical movement patterns throughout the year, as they move from deeper to shallower waters at night, most likely following the movement patterns of prey (Andrews et al. 2009). Utilization of shallow water habitat observed in Puget Sound may negatively affect sixgill populations over time due to exposure to polluted effluents and the potential for over-harvest by recreational and commercial fishers causing local extirpations (Rupp 2001).

Over fishing of large long lived elasmobranchs like sixgills may cause population bottlenecks that negatively impact population genetics. Genetic diversity of a species is a fundamental concern to conservation biologists because it is the basic tool allowing populations to adapt to environmental changes, novel situations and to rebound from population bottlenecks (Frankham 1996). There are few in-depth genetic diversity studies using microsatellite neutral nuclear markers in large shark species. Those that exist report low to moderate genetic diversity in the form of expected heterozygosity; $H_{E}$ : range of $0.12-0.95$ for blacktip reef sharks, Carcharhinus limbatus (Keeney et al. 2005); 0.23-0.53 for sandbar sharks, Carcharhinus plumbeus (Heist and Gold 1999); 0.61-0.97 for lemon sharks, Negaprion brevirostris (Feldheim et al. 2001; Portnoy et al. 2007); 0.17-0.90 for nurse sharks, Ginglymostoma cirratum (Heist et al. 2003); 0.45-0.95 for great white sharks, Carcharodon carcharias (Pardini et al. 2000); 0.47-0.81 for grey nurse shark, Carcharias Taurus (Ahonen et al. 2009); 0.40-1.00 for whale shark, Rhincodon typus (Schmidt et al. 2009); and 0.35-0.86 for the shortspine spurdog, Squalus mitsukurii (Daly-Engel et al. 2010). Using mtDNA, Hoelzel et al. (2006) compared basking shark, Cetorhinus maximus, genetic diversity to other widespread pelagic elasmobranch species such as blacktip reef sharks and white sharks. They found basking sharks to have low genetic diversity compared to other pelagic shark species, as well as other widespread pelagic species such as bottlenose dolphins, Tursiops truncates, and orcas, Orcinas orcas (Hoelzel et al. 2006).

The low genetic diversity found within some shark taxa is thought to be due to the relatively slow rate of molecular evolution found in sharks (7-8 times slower than primates Martin et al. 1992), or due to widespread historical population bottlenecks (Hoelzel et al. 2006). However, if low mutation rates are driving low genetic diversity within sharks then why do some species report mid to high genetic diversity (Feldheim et al. 2001; Portnoy et al. 2007)? One hypothesis explaining higher genetic diversity in sharks is the mating system found in many species. Polyandry (females mating with more than one male), polygyny (males mating with more than one female), and multiple paternity within a litter is recognized in many shark species (Feldheim et al. 2002; Portnoy et al. 2007; DiBattista et al. 2008; Daly-Engel et al. 2007, 2010). Multiple paternity obviously results in increased diversity within a litter but, due to variance in reproductive success among males noted in many shark species, increased diversity is not likely seen at the population level (Karl 2008; Daly-Engel et al. 2010). In fact, Daly-Engel et al. (2010) compared published estimates of percent multiple paternity and genetic diversity within shark species and found no significant correlation.

Sixgill sharks tend to spend a significant amount of time in their hypothesized nursery area, Puget Sound, WA, USA (Andrews et al. 2010). Their movement patterns suggest relatively small home ranges and site fidelity until they are documented leaving Puget Sound (Andrews et al. 2010). This localized pattern of sixgill abundance offered a unique opportunity to sample multiple sharks within relatively small areas of time and space. In this study, we investigated the genetic diversity and relatedness of sixgill sharks found within Puget Sound. Specifically, we asked two questions: (1) How much genetic diversity is found within sixgill 
sharks in Puget Sound? and (2) What is the level of genetic relatedness within and among sixgills in Puget Sound? In addition, we were able to opportunistically investigate multiple paternity within a single litter from a female having 71 full term pups when she beached in southern Puget Sound.

\section{Methods}

\section{Study location}

Puget Sound is a fjord-like estuary located in northwest Washington State and covers an area of about $2,330 \mathrm{~km}^{2}$, including 3,700 km of coastline. The human population in the greater Puget Sound region is about 3.6 million, and $52 \%$ of the shoreline in the main Puget Sound basin has been modified by human activities (Puget Sound Action Team State of the Sound Report 2009, http://www.psp.wa. gov/sos2009.php).

\section{Field collections}

We collected DNA tissue samples from over 300 sixgill sharks in Puget Sound from 2003-2007. DNA samples were collected from sixgill sharks beneath the Seattle Aquarium $(n=29)$ every other month from 2003 to 2005 or from sharks collected during 107 longline sets conducted by WDFW and NOAA Fisheries from 2003 to 2007 $(n=295)$. During genetic sampling, sharks were externally marked with disk and/or Floy ${ }^{\circledR}$ tags for possible identification in the future.

At the Seattle Aquarium, a $3 \mathrm{~m}^{2}$, partially enclosed underwater research station was constructed at $20 \mathrm{~m}$ depth to observe, videotape, tag, and collect DNA samples from sixgill sharks. To attract sharks, 2001 of fresh frozen fish carcasses were placed $1 \mathrm{~m}$ west of the research area during bi-monthly research events. SCUBA divers used an extendable Seahorse Graphite $2.1 \mathrm{~m}$ pole spear with a biopsy punch to collect 2-3 mm-diameter DNA samples in situ from along the lateral surface dorsal to the lateral line without restraint of the shark (Kohler and Turner 2001). During longline fishing operations conducted from 2003 to 2007 (Williams et al. 2010), WDFW and NOAA collected a $0.5 \mathrm{~cm}^{2}$ DNA sample from the caudal fin of each sixgill shark.

A "set" for the Seattle Aquarium consisted of all sharks sampled during the $48 \mathrm{~h}$ in each of the bi-monthly research events, while a "set" for longline sampling included all sharks collected on the same longline set. Geographic distribution of sets is shown in Fig. 1, while complete descriptions of longline sets (date, latitude and longitude, set time and number of sixgills caught) is found in Appendix Table 4.

The presence and extent of multiple paternity within a litter was investigated by examining samples from a pregnant female and her pups when she stranded on a beach near Shelton, WA in south Puget Sound on January 21, 2007. A total of 71 pups were sampled, in addition to the mother.

\section{Sample processing}

Tissue samples were preserved in $70-100 \%$ ethanol or frozen at -20 or $-65^{\circ} \mathrm{C}$ until analysis. DNA was extracted from tissue using the DNeasy Blood and Tissue Kit (Qiagen, Valencia, California). Initial microsatellite amplification, screening, and scoring followed Larson et al. (2009). Preliminary analyses showed all loci exhibited null alleles (average of 0.19 ) in all 15 loci tested. In an effort to decrease the presence of null alleles, primers were redesigned using Primer 3 software (v. 0.4.0, Rozen and Skaletsky 2000) for a resulting suite of ten loci showing zero genotyping failure rates (Genepop $\mathrm{v}$ 4.0.10, option 8, estimate rate of genotyping failures, Raymond and Roussett 1995). All loci were amplified at $57^{\circ} \mathrm{C}$.

\section{Data analysis}

We examined genetic diversity within sixgill sharks in Puget Sound using ten microsatellite loci. General descriptive statistics of the loci was determined using GENEPOP 4.0.10 (Raymond and Roussett 1995) and FSTAT 2.9.3.2 (Goudet 1995). GENEPOP was used to determine Hardy-Weinberg equilibrium ( $\mathrm{F}_{\mathrm{IS}} P$ values), heterozygosity, linkage disequilibrium and genotyping failures such as null alleles and other errors. FSTAT was used to determine allelic richness. This is an alternate measure of the number of alleles per locus applying a rarefaction method to standardize alleles per locus to a uniform size.

To determine the relative stability of the genetic diversity measured over time BOTTLENECK software was used (Cornuet and Luikart 1997). This program computes for each population sample, and for each locus, the distribution of the heterozygosity expected from the observed number of alleles under the assumption of mutation-drift equilibrium. The program enables the computation of a $P$ value for the observed heterozygosity and allele frequency distribution to see whether it is as expected under mutationdrift equilibrium or if there has been a shift provoked by recent bottlenecks (Cornuet and Luikart 1997).

To determine the probable number of distinct populations found in Puget Sound we employed the program STRUCTURE 2.3.3 (Pritchard et al. 2000). This program calculates the likely number of populations $(\mathrm{K})$ and also 
Fig. 1 Location of sixgill samples collected from longline sets between 2003 and 2007 and from scuba biopsies between 2003 and 2005 in Puget Sound, WA. Details of longline sets can be found in Appendix Table 4

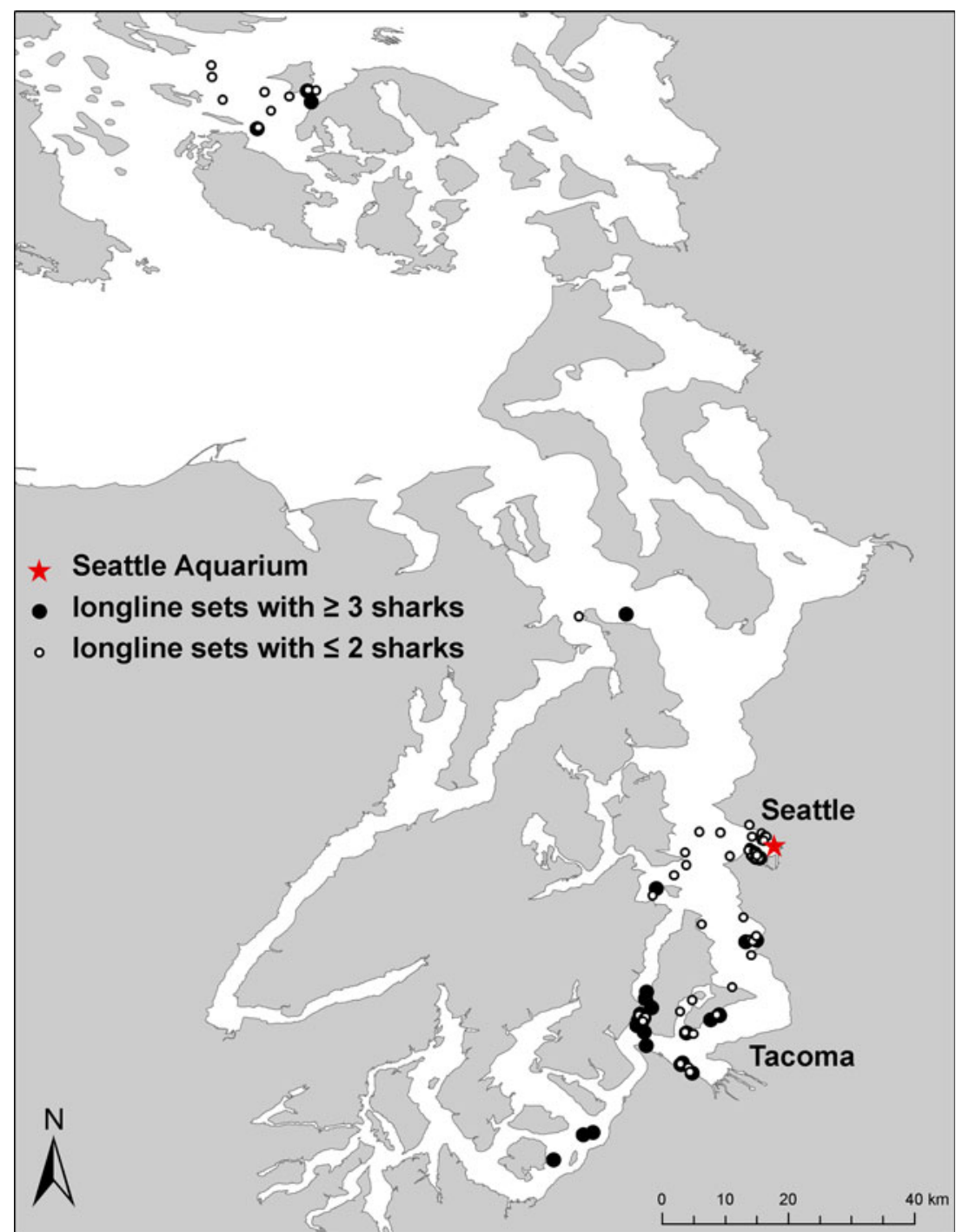

assigns individuals to populations. We used the model with a 10,000 burn in length and 10,000 simulations to test $\mathrm{K}$ range from 1 to 19 . It is often applied to multiple genetic markers such as microsatellites and can accommodate deviations from Hardy-Weinberg equilibrium.

Several programs were employed to determine mating pattern. First GERUD 2.0 (Jones 2005) was used to estimate the minimum number of fathers contributing to the female sixgill's litter given the female's and the offspring's genotypes. Second, since GERUD suggested multiple fathers, PrDM 1 (Neff et al. 2002) was used to calculate the probability of detecting multiple mating by the markers employed and their allelic variation. It considers the allelic variation in offspring and the potential number of sires given reproductive skew of each sire. It assumes single sex multiple mating (polyandry or polygyny) where all offspring are either full or half siblings. Finally COLONY 1.2 (Wang 2004) was used to estimate the probable number of fathers siring a female's litter. It takes into account multiple mating systems and skewed reproductive success as well as factoring in genotyping errors such as null alleles.

Several programs were then used to determine relatedness. First MLRELATE (Kalinowski et al. 2006) was used to determine relatedness among and between individuals in the dataset. This program calculates maximum likelihood estimates of relatedness and relationship. It is designed for microsatellite data and can accommodate null alleles. Next to corroborate results, KINGROUP 1 (Konovalov et al. 2004) was used to determine relatedness among and between individuals in the dataset. It is a program for pedigree relationship reconstruction and kin group assignments using genetic markers considering deviations from HardyWeinberg equilibrium. Finally COLONY 1.2 (Wang 2004) was employed to assign individuals to sibling groups. This program clusters full sibling families with half sibling 
families using multilocus data, such as microsatellites. It uses group maximum likelihood ratios to partition individuals into sibling groups and takes into account multiple mating systems and skewed reproductive success as well as factoring in genotyping errors such as null alleles.

Multiple programs for determining multiple paternity and relatedness were employed to strengthen interpretation of results.

Sequential Bonferroni adjustments were applied to correct for multiple comparisons across all loci $(n=10)$, for an adjusted significance value of $P=0.005$ for descriptive statistics of genetic results (Rice 1989).

\section{Results}

Genetic diversity

The average number of microsatellite alleles per locus was 12 (range 5-26), average allelic richness was 8 (range 4-16), the average expected heterozygosity $\left(\mathrm{H}_{\mathrm{E}}\right)$ was 0.61 (range 0.08 to -0.90 ), and the average observed heterozygosity $\left(\mathrm{H}_{\mathrm{O}}\right)$ was 0.45 (range $0.08-0.96$ ) (Table 1).
Observed heterozygosity in most loci (six of ten) was lower than expected heterozygosity. We found no evidence of allelic disequilibrium and no genotyping failures (GENEPOP). Departures from Hardy-Weinberg expectations were significant for five of the ten microsatellite loci employed (significant $\mathrm{F}_{\mathrm{IS}} P$ values, Bonferroni corrected initial $\alpha=0.005$, Table 1 ). Four out of the five loci which failed Hardy-Weinberg equilibrium exhibited an excess of homozygotes. Null alleles were found at half of the loci (GENEPOP: average frequency 0.09; range 0.00-0.34). Analysis of genetic stability of the sampled sixgill population suggested that the allele frequency distribution was expected within a population has been stable over time (BOTTLENECK: over all loci non-significant allele frequency departure, $P=0.31$ ).

Population structure

We found no evidence for more than one population of sixgill sharks in Puget Sound from all samples collected from 2003 to 2007. Estimates of posterior probabilities approached one, suggesting no genetic structure (STRUCTURE and COLONY).

Table 1 Microsatellites amplified in sixgill shark samples

\begin{tabular}{|c|c|c|c|c|c|c|c|c|c|c|c|}
\hline Locus & Primer direction & Primer sequences & Bankit \# & Size range & A & $\mathrm{Ar}$ & $\mathrm{H}_{\mathrm{e}}$ & $\mathrm{H}_{\mathrm{o}}$ & $\mathrm{F}_{\text {is }}$ & $P$ & $\%$ null \\
\hline \multirow[t]{2}{*}{$\operatorname{sg} 05$} & $\mathrm{~F}$ & TCTCACATACCCCATC & 1147999 & $117-251$ & 9 & 4 & 0.08 & 0.08 & -0.01 & 1.00 & 0.00 \\
\hline & $\mathrm{R}$ & TTCAТTТСССТССТССТССТ & & & & & & & & & \\
\hline \multirow[t]{2}{*}{$\operatorname{sg} 10$} & $\mathrm{~F}$ & TGCGAGAGTGTGTGTGTA & 1148004 & $155-345$ & 21 & 14 & 0.84 & 0.96 & -0.12 & 0.73 & 0.00 \\
\hline & $\mathrm{R}$ & GGCGTCAGTGTTCACATGC & & & & & & & & & \\
\hline \multirow[t]{2}{*}{$\operatorname{sg} 11$} & $\mathrm{~F}$ & GTCACCATTAGGACCATTGCTCT & 1148005 & $120-250$ & 26 & 16 & 0.90 & 0.39 & 0.52 & 0.00 & 0.22 \\
\hline & $\mathrm{R}$ & CACTTACAGTCCTCTTGACAAATCA & & & & & & & & & \\
\hline \multirow[t]{2}{*}{$\operatorname{sg} 13$} & $\mathrm{~F}$ & TCGTGTTATTAATGGGAGGCCTGT & 1148009 & $131-271$ & 9 & 6 & 0.65 & 0.60 & -0.12 & 0.00 & 0.01 \\
\hline & $\mathrm{R}$ & TGTTTGTGTATGTGCATTGTTG & & & & & & & & & \\
\hline \multirow[t]{2}{*}{$\operatorname{sg} 24$} & $\mathrm{~F}$ & CGTTCACACGAATCTCCTC & 1148010 & $104-131$ & 9 & 9 & 0.52 & 0.17 & 1.00 & 0.01 & 0.27 \\
\hline & $\mathrm{R}$ & TGAAAGCCTCAATTGGAGAA & & & & & & & & & \\
\hline \multirow[t]{2}{*}{$\operatorname{sg} 25$} & $\mathrm{~F}$ & TGGAGCAGGCTGATGAGGCAC & 1148015 & $143-165$ & 8 & 5 & 0.52 & 0.58 & -0.20 & 0.13 & 0.00 \\
\hline & $\mathrm{R}$ & TGACATGTGTTTGCGAGGTT & & & & & & & & & \\
\hline \multirow[t]{2}{*}{$\operatorname{sg} 27$} & $\mathrm{~F}$ & TCATGTCACGCTACACGTAA & 1148025 & $172-220$ & 10 & 5 & 0.66 & 0.82 & -0.28 & 0.04 & 0.00 \\
\hline & $\mathrm{R}$ & CGTTGTCAAGGCAATCAGAC & & & & & & & & & \\
\hline \multirow[t]{2}{*}{$\operatorname{sg} 28$} & $\mathrm{~F}$ & TGAAGGCTGACAAACAGGCT & 1148029 & $149-361$ & 6 & 5 & 0.69 & 0.46 & 0.35 & 0.00 & 0.08 \\
\hline & $\mathrm{R}$ & GCTCTGTTGCTCTGCACAAT & & & & & & & & & \\
\hline \multirow[t]{2}{*}{$\operatorname{sg} 32$} & $\mathrm{~F}$ & CTGTCCATTTGCTCAATCTGT & 1148835 & $108-160$ & 13 & 10 & 0.78 & 0.14 & 0.77 & 0.00 & 0.34 \\
\hline & $\mathrm{R}$ & GGCCGCTCTAGAACTAGTGGA & & & & & & & & & \\
\hline \multirow[t]{2}{*}{$\operatorname{sg} 33$} & $\mathrm{~F}$ & TCTGTCTTATTTGTCTGACTCCA & 1148839 & $235-355$ & 5 & 5 & 0.51 & 0.36 & 0.82 & 0.00 & 0.05 \\
\hline & $\mathrm{R}$ & AAAGTGCAAGACAGAGGGAGA & & & & & & & & & \\
\hline AVE & & & & & 12 & 8 & 0.61 & 0.45 & & & 0.09 \\
\hline
\end{tabular}

All loci were run at an annealing temperature of $57^{\circ} \mathrm{C}$

$A V E$ averages, Bankit \# Genebankbankit sequence \#, $A$ alleles, $A r$ allelic richness, $H_{e}$ expected heterozygosity, $H_{o}$ observed heterozygosity, FIS Hardy-Weinberg equilibrium $P$ value (Genepop v 4.1.10) 
Table 2 Average proportional relatedness of sixgill sharks caught within (same time and place) and among sets

\begin{tabular}{lllll}
\hline Program & HS & FS & Unrelated & Total related \\
\hline MLRELATE within & 0.27 & 0.60 & 0.13 & 0.87 \\
MLRELATE among & 0.04 & 0.19 & 0.77 & 0.23 \\
KINGROUP within & 0.45 & 0.20 & 0.35 & 0.65 \\
KINGROUP among & 0.13 & 0.03 & 0.84 & 0.16 \\
COLONY assignments & 0.60 & 0.23 & 0.17 & 0.83 \\
Averages within & 0.44 & 0.34 & 0.22 & 0.78 \\
Averages among & 0.09 & 0.10 & 0.81 & 0.19 \\
\hline
\end{tabular}

All $t$-tests comparing proportion of relatedness within and among sets were significant $(P<0.001)$

$H S$ half sibling, $F S$ full sibling

\section{Relatedness within Puget Sound}

We found a high degree of relatedness within sixgill sharks sampled during the same set (at the same time and place; Table 2). The average proportion of individuals related to each other within sets (MLRELATE: 0.60 full siblings $(\mathrm{FS})+0.27$ half-siblings $(\mathrm{HS})=0.87$ total related; KINGROUP: $0.20 \mathrm{FS}+0.45 \mathrm{HS}=0.65$ total related) was significantly greater than $(t$-test $P<0.001)$ the average proportion of individuals unrelated to each other (MLRELATE: 0.13 unrelated (U); KINGROUP: $0.35 \mathrm{U}$ ). In contrast, the average proportion of individuals related to each other among sets (MLRELATE: 0.19 FS + 0.04 $\mathrm{HS}=0.23$ total related; KINGROUP: $0.03 \mathrm{FS}+0.13$ HS $=0.16$ total related) was significantly less than ( $t$-test $P<0.001)$ the average proportion of individuals unrelated to each other (MLRELATE: $0.77 \mathrm{U}$; KINGROUP: 0.84). Tests for assumptions of normality and independence for $t$ tests were met. COLONY identified a total of thirty-three sibling cohorts within sampled Puget Sound sixgills.

Relatedness within a litter

The number of males which contributed to the 71-pup litter obtained from a stranded female shark in 2007 varied among analyses. GERUD suggested at least six fathers contributed to the genotypes. COLONY suggested nine males contributed to the litter's genotypes, with skewed reproductive success in which four males contributed to $80 \%$ of the pups (range $10-45 \%$ ), while five other males contributed little to the brood (range 1-5\%). PrDM was used to determine the statistical power of the microsatellite markers to detect multiple paternity. It concluded, with high probability $(P=0.99)$ of detecting multiple paternity with skewed reproductive success. Thus statistical power to detect multiple paternity was high.

\section{Discussion}

Overall, genetic diversity of sixgill sharks in Puget Sound was moderate $\left(H_{E}=0.61\right)$ compared with other shark species using similar methods: heterozygosity ranges from 0.17 to 0.97 (Table 3). Allelic richness, an alternate measurement of the number of alleles per locus allowing for comparison between samples of different size, has not been widely reported in elasmobranchs, but sixgills seem to fall in the high to normal range (Table 3). Our analysis shows that sixgills in Puget Sound have maintained allelic diversity expected under mutation-drift theory and have not suffered from a historical bottleneck affecting microsatellite diversity. Finally our estimates of allelic stability, paternity and relatedness are likely conservative because some loci show deviations from Hardy-Weinberg equilibrium.

Analysis of genetic contributions to the one female sixgill's litter found polyandry in which there was strong evidence of multiple paternity. At least six males contributed to her offspring, but these contributions were skewed because only a few of the males contributed the majority of the genotypes. This is not surprising, as there has been evidence of multiple paternity using similar genetic methods found in every shark species examined thus far (lemon sharks, Feldheim et al. 2002; sandbar sharks, Portnoy et al. 2007; and Pacific spiny dogfish, Squalus suckleyi (S. Larson unpublished data). Most studies on
Table 3 Genetic diversity of microsatellite loci presented in nine elasmobranch species

\begin{tabular}{lcll}
\hline Species & HE range & Allelic richness ave. & Source \\
\hline Hexanchusgriseus & $0.08-0.90$ & 8.00 & This study \\
Squalusmitsukurii & $0.35-0.86$ & 8.35 & Daly-Engel et al. (2010) \\
Rhincodontypus & $0.40-1.00$ & 4.20 & Schmidt et al. (2009) \\
Carchariastaurus & $0.47-0.81$ & 3.32 & Ahonen et al. (2009) \\
Negaprionbrevirostris & $0.61-0.97$ & Not reported & Portnoy et al. (2007) \\
& & & Feldheim et al. (2001) \\
Carcharhinuslimbatus & $0.12-0.95$ & Not reported & Keeney et al. (2005) \\
Ginglymostomacirratum & $0.17-0.90$ & Not reported & Heist et al. (2003) \\
Carcharodoncarcharias & $0.45-0.95$ & Not reported & Pardini et al. (2000) \\
Carcharhinusplumbeus & $0.23-0.53$ & Not reported & Heist and Gold (1999) \\
\hline
\end{tabular}


multiple paternity in sharks have also documented skewed reproductive success with one or two males siring the majority of the offspring (Chapman et al. 2004; Portnoy et al. 2007). This may drive selection for males to bias paternity and increase fitness through intrasexual competition (Portnoy et al. 2007).

Genetic diversity within sharks may be affected by this polyandrous mating system. Daly-Engel et al. 2007 documented a positive but non-significant correlation ( $R^{2}=0.40, P=0.184$ ) between population allelic richness and percent multiple paternity in five studies using microsatellite markers. Genetic diversity within a single female's litter is obviously increased by genetic contributions from multiple males. However due to the variance or skew in male reproductive success as noted in this study and others, the increase in genetic diversity at the population level is thought to be negligible (Daly-Engel et al. 2007).

The genetic benefit of polyandry for males is obvious in that the more pups a male sires, the greater his reproductive fitness. However, the cost/benefit to the female is unclear and may be high due to injuries commonly associated with shark mating behavior (Portnoy et al. 2007). A female's optimal mating strategy is one that balances her costs to the fitness benefits of mating. The most accepted hypothesis regarding the evolution of polyandry within sharks is the encounter rate theory (Daly-Engel et al. 2007). This suggests polyandry is driven by the number of males a female encounters during a breeding season. In high density populations, females would have more chances to encounter males and thus polyandry would increase. Alternatively, in aggregate mating areas, males may outnumber females and may exhibit mobbing or herding behavior to force females to mate (Whitney et al. 2004; Daly-Engel et al. 2007;
Portnoy et al. 2007; DiBattista et al. 2008). This may be the case for species in which the females have reproductive cycles greater than one year, which is thought to be true in sixgills (Ebert 2002; Capapé et al. 2004). In this situation, two potential hypotheses may explain the occurrence of polyandry. First, males may visit mating grounds annually, but the number of females present in the mating grounds may be lower, thus limiting a male's access to females and increasing competition for mates (Portnoy et al. 2007; DiBattista et al. 2008). Second, if reproductive cycles are annual in both sexes then this may decrease potential competition for mates, but would simply increase the chances of females mating with multiple mates over their reproductive cycle. It seems most likely that female sixgills are polyandrous as a matter of convenience to avoid aggression from multiple males in either hypothesis (similar to lemon sharks, Dibattista et al. 2008, and shortspine spurdog, Daly-Engel et al. 2010).

Sixgill sharks caught in Puget Sound averaged $212.86 \pm 2.36 \mathrm{~cm}$ in total length and ranged from 109 to $334 \mathrm{~cm}$ (Fig. 2). As sexual maturation occurs at approximately $3 \mathrm{~m}$ in males and $4 \mathrm{~m}$ in females (Ebert 2002 and 2003), nearly all specimens (99\%) sampled were subadults (only 4 out of 296 measured were $\geq 3 \mathrm{~m}$ ). It is likely that many of these sharks are at least 5 years old based on observations that pups are born at $\sim 70 \mathrm{~cm}$ (Fig. 2) and then double in size during their first year of life (Ebert 2002, 2003), and growth for a $200 \mathrm{~cm}$ shark is thought to be approximately $12-13 \mathrm{~cm} /$ year based on one individual recaptured after being at liberty for 29 months (Andrews et al. 2009).

Sharks collected at the same time and place tend to have a high proportion of related individuals (Table 2). The data
Fig. 2 Total lengths (nose to tip of tail) in $\mathrm{cm}$ of sixgills caught during tagging operations

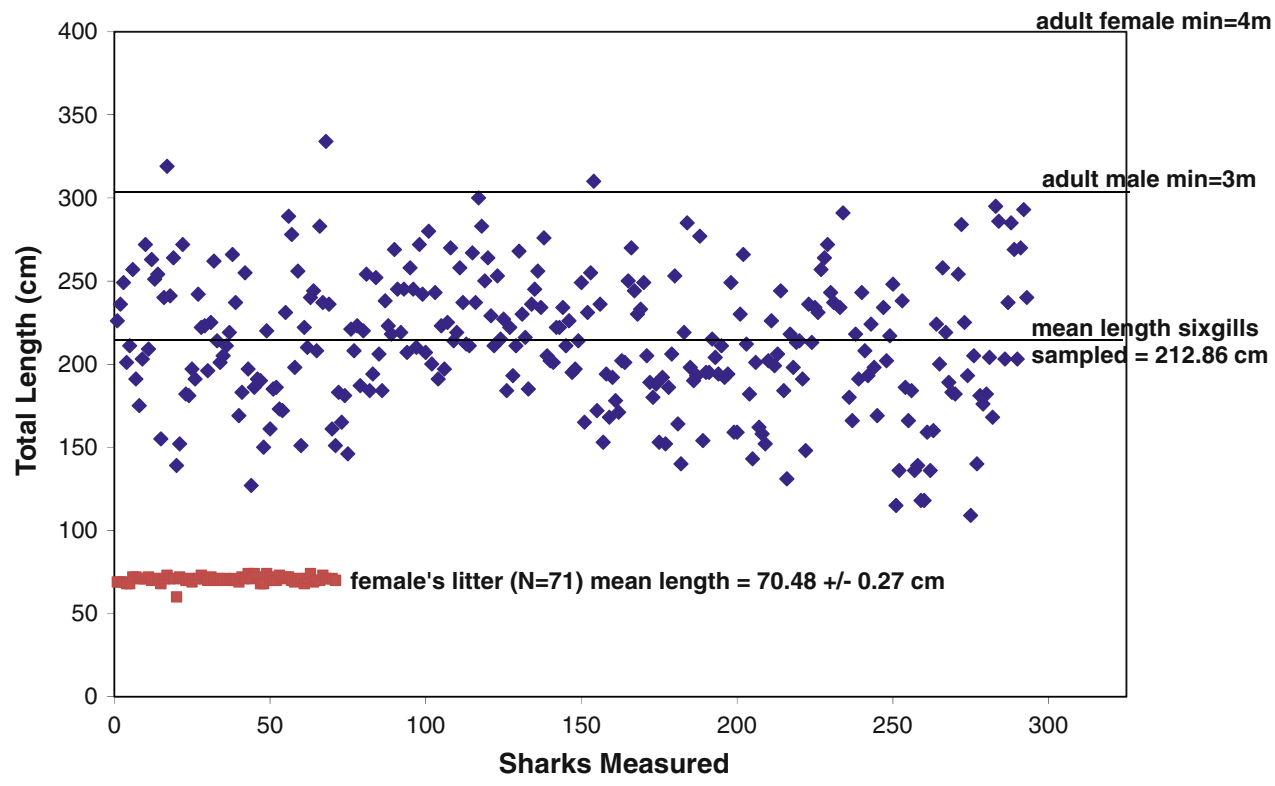


suggest $65-87 \%$ of sharks collected in the same set are related as full or half siblings. Andrews et al. (2007) found that juvenile sharks in Puget Sound remain within relatively small areas at certain times of the year, with the maximum displacement being 8.4-29.2 km. Some half to full sibling sharks have also been acoustically tracked together making simultaneous vertical movements over 24hour periods (Andrews et al. 2009). Thus, it appears that individuals within the same litter, even half siblings, may associate with one another for long periods of time. The reason why sixgills form these associations is unknown, but there may be behavioral advantages, such as increased foraging success or an increased ability to detect predators (Hamilton 1963, 1964; Griffin and West 2003). Alternatively, sharks born in the same location may simply be found together over time because they are similarly associated with their natal habitat.

A handful of studies have found spatiotemporal kin association in the aquatic environment (Planes et al. 1993; Olsén et al. 2004; Selkoe et al. 2006; Miller-Sims et al. 2008; Buston et al. 2009; Sikkel and Fuller 2010). Over half these studies found high levels of relatedness among fish within discrete aggregations (Miller-Sims et al. 2008; Olsén et al. 2004; Sikkel and Fuller 2010). This level of association has been demonstrated in the demersal livebearing black perch, Embiotoca jacksoni (Sikkel and Fuller 2010), the benthic nesting humbug damselfish, Dascyllus aruanus (Buston et al. 2009), the midwater aggregate spawning kelp bass, Paralabrax clathratus (Selkoe et al. 2006), and the riverine benthic nesting Atlantic salmon, Salmo salar (Olsén et al. 2004). Kinship associations are not generally expected for species with the capacity to disperse long distances and mix randomly during planktonic phases (Selkoe et al. 2006; Buston et al. 2009). Associations among related sixgills may be attributable to simultaneous birth and recruitment into a nursery area where they remain for several years until they approach maturity. Eventually they are thought to reach a certain length and/or age when they leave Puget Sound for the open ocean (Andrews et al. 2010).

Sub-adult sixgill sharks residing in Puget Sound constitute a single genetically intermixing population with a high proportion of related individuals occurring at the same time and in shared space. As this is the first analysis of its kind for sixgills, the uniqueness of Puget Sound in this regard cannot be fully evaluated. The genetic structure of adult sixgills found on the outer coast in the Northeast Pacific, the entire Pacific, and the rest of the world remains unknown. Additionally, movement patterns of adult sixgills the world over are poorly understood and limited to shortterm samples (Carey and Clark 1995); however there is documentation of one sixgill moving from Puget Sound,
WA to Point Reyes, CA ( $>1200 \mathrm{~km}$ distance) during a seven-month period (Andrews et al. 2010). Thus, the potential for individuals to mix and interbreed at least along the continental margins is high, and genetic samples and descriptions of movement patterns from other regions would help understand the relative importance of the Puget Sound sub-adult population in the context of the greater sixgill population structure.

Given the long lifespan of sixgills, their assumed biannual reproductive cycle, and their potential capacity to travel long distances, it is possible that Puget Sound serves as pupping and nursery grounds for a population that is broadly distributed. If this is the case, the closure of Puget Sound to sixgill harvest could serve as an effective conservation measure that protects a significant number of subadult sixgills during the first several years of development, providing them a chance to mature and recruit to a single oceanic stock. Simpfendorfer (1999) pointed out that the most important age class to protect for maintaining a positive rate of shark population increase was juveniles nearing maturity or sub-adults. High mortality rates of subadults along with the exploitation of adults leads to reductions in the number of pups in nursery areas and lower overall recruitment (Kinney and Simpfendorfer 2009). This is more pronounced in slow growing, long lived species such as sixgills. For populations in decline or under diverse and ever intensifying pressures, such as more than half the known shark species, understanding and ultimately conserving the genetic variability of the population may increase its ability to withstand environmental changes or anthropogenic stressors (Frankham 1996; Keller and Waller 2002).

Acknowledgments We would like to thank P.S. Levin and G.D. Williams of NOAA, G. Bargmann and D. Farrer of WDFW for helping to collect tissue samples. Longline data was generously provided by G. Bargmann and D. Farrer with WDFW. Biopsy samples were collected at the Seattle Aquarium by staff and volunteer divers J. Hollander, T. Carpenter, and B. Hatch. This research was supported primarily by the Seattle Aquarium and the Seattle Aquarium Society general operating funds. It was also supported by the Foley Frischkorn Wildlife Conservation Fund. We wish to thank retired directors B. Arntz and J. Braden, retired life sciences curator P. McMahon, acting director B. Davidson, and life sciences curator C.J. Casson for their ongoing support.

Open Access This article is distributed under the terms of the Creative Commons Attribution Noncommercial License which permits any noncommercial use, distribution, and reproduction in any medium, provided the original author(s) and source are credited.

\section{Appendix}

See Table 4. 
Table 4 Details of longline sets for sixgill sharks conducted by WDFW and NOAA from 2003 to 2007

\begin{tabular}{|c|c|c|c|c|c|c|c|c|}
\hline Year & Agency & Area fished & $\begin{array}{l}\text { Date gear } \\
\text { set }\end{array}$ & Latitude & Longitude & $\begin{array}{l}\text { Min } \\
\text { depth (ft) }\end{array}$ & $\begin{array}{l}\text { Max } \\
\text { depth (ft) }\end{array}$ & $\begin{array}{l}\text { Total sixgill } \\
\text { caught }\end{array}$ \\
\hline 2003 & WDFW & Dalco Passage & $7 / 30 / 03$ & $47^{\circ} 21^{\prime} 781^{\prime \prime}$ & $122^{\circ} 32^{\prime} 333^{\prime \prime}$ & 180 & 288 & 9 \\
\hline 2003 & WDFW & Tolva Shoal & $7 / 30 / 03$ & $47^{\circ} 11^{\prime} 642^{\prime \prime}$ & $122^{\circ} 36^{\prime} 393^{\prime \prime}$ & 282 & 522 & 10 \\
\hline 2003 & WDFW & Balch Passage & $7 / 31 / 03$ & $47^{\circ} 11^{\prime} 453^{\prime \prime}$ & $122^{\circ} 37^{\prime} 227^{\prime \prime}$ & 516 & 534 & 6 \\
\hline 2003 & WDFW & Sandy Point & $7 / 31 / 03$ & $47^{\circ} 09^{\prime} 310^{\prime \prime}$ & $122^{\circ} 39^{\prime} 762^{\prime \prime}$ & 438 & 480 & 17 \\
\hline 2003 & WDFW & Colvos Passage & $7 / 31 / 03$ & $47^{\circ} 21^{\prime} 188^{\prime \prime}$ & $122^{\circ} 32^{\prime} 507^{\prime \prime}$ & 300 & 384 & 14 \\
\hline 2003 & WDFW & Colvos Passage & $8 / 1 / 03$ & $47^{\circ} 23^{\prime} 086^{\prime \prime}$ & $122^{\circ} 31^{\prime} 895^{\prime \prime}$ & 324 & 390 & 5 \\
\hline 2003 & WDFW & Foulweather Bluff & $9 / 29 / 03$ & $47^{\circ} 56^{\prime} 007^{\prime \prime}$ & $122^{\circ} 33^{\prime} 550^{\prime \prime}$ & 198 & 384 & 3 \\
\hline 2003 & WDFW & Entrance to Hood Canal & $9 / 29 / 03$ & $47^{\circ} 55^{\prime} 815^{\prime \prime}$ & $122^{\circ} 37^{\prime} 580^{\prime \prime}$ & 228 & 444 & 0 \\
\hline 2003 & WDFW & Colvos Passage & $9 / 30 / 03$ & $47^{\circ} 21^{\prime} 774^{\prime \prime}$ & $122^{\circ} 32^{\prime} 315^{\prime \prime}$ & 156 & 324 & 22 \\
\hline 2003 & WDFW & Colvos Passage & $9 / 30 / 03$ & $47^{\circ} 21^{\prime} 240^{\prime \prime}$ & $122^{\circ} 32^{\prime} 156^{\prime \prime}$ & 240 & 240 & 26 \\
\hline 2003 & WDFW & Point Dalco & $9 / 30 / 03$ & $47^{\circ} 20^{\prime} 224^{\prime \prime}$ & $122^{\circ} 31^{\prime} 986^{\prime \prime}$ & 192 & 288 & 10 \\
\hline 2003 & WDFW & Colvos Passage & $10 / 1 / 03$ & $47^{\circ} 20^{\prime} 804^{\prime \prime}$ & $122^{\circ} 32^{\prime} 637^{\prime \prime}$ & 138 & 240 & 12 \\
\hline 2003 & WDFW & Colvos Passage & $10 / 1 / 03$ & $47^{\circ} 22^{\prime} 317^{\prime \prime}$ & $122^{\circ} 31^{\prime} 373^{\prime \prime}$ & 216 & 378 & 5 \\
\hline 2003 & WDFW & Colvos Passage & $10 / 1 / 03$ & $47^{\circ} 23^{\prime} 661^{\prime \prime}$ & $122^{\circ} 31^{\prime} 807^{\prime \prime}$ & 138 & 390 & 11 \\
\hline 2004 & WDFW & Colvos Passage & $9 / 21 / 2004$ & $47^{\circ} 21^{\prime} 464^{\prime \prime}$ & $122^{\circ} 32^{\prime} 021^{\prime \prime}$ & 210 & 294 & 11 \\
\hline 2004 & WDFW & Colvos Passage & $9 / 22 / 2004$ & $47^{\circ} 21^{\prime} 676^{\prime \prime}$ & $122^{\circ} 32^{\prime} 475^{\prime \prime}$ & 204 & 318 & 1 \\
\hline 2004 & WDFW & Owen's Beach & $9 / 22 / 2004$ & $47^{\circ} 19^{\prime} 085^{\prime \prime}$ & $122^{\circ} 31^{\prime} 833^{\prime \prime}$ & 144 & 174 & 7 \\
\hline 2004 & WDFW & Maury Island & $9 / 22 / 2004$ & $47^{\circ} 21^{\prime} 727^{\prime \prime}$ & $122^{\circ} 25^{\prime} 571^{\prime \prime}$ & 432 & 588 & 10 \\
\hline 2004 & WDFW & Colvos Passage & $9 / 23 / 2004$ & $47^{\circ} 21^{\prime} 410^{\prime \prime}$ & $122^{\circ} 32^{\prime} 059^{\prime \prime}$ & 198 & 294 & 2 \\
\hline 2004 & WDFW & Les Davis Pier & $9 / 23 / 2004$ & $47^{\circ} 16^{\prime} 717^{\prime \prime}$ & $122^{\circ} 27^{\prime} 907^{\prime \prime}$ & 138 & 162 & 14 \\
\hline 2004 & WDFW & Piner Point & $9 / 24 / 2004$ & $47^{\circ} 21^{\prime} 276^{\prime \prime}$ & $122^{\circ} 26^{\prime} 313^{\prime \prime}$ & 498 & 576 & 15 \\
\hline 2004 & WDFW & Quartermaster Harbor & $9 / 24 / 2004$ & $47^{\circ} 20^{\prime} 168^{\prime \prime}$ & $122^{\circ} 28^{\prime} 405^{\prime \prime}$ & 150 & 180 & 17 \\
\hline 2004 & WDFW & Les Davis Pier & $9 / 25 / 2004$ & $47^{\circ} 16^{\prime} 875^{\prime \prime}$ & $122^{\circ} 28^{\prime} 006^{\prime \prime}$ & 120 & 204 & 0 \\
\hline 2004 & WDFW & Les Davis Pier & $9 / 25 / 2004$ & $47^{\circ} 17^{\prime} 447^{\prime \prime}$ & $122^{\circ} 28^{\prime} 856^{\prime \prime}$ & 480 & 504 & 8 \\
\hline 2004 & WDFW & Presidents Channel & $10 / 8 / 2004$ & $48^{\circ} 39^{\prime} 889^{\prime \prime}$ & $123^{\circ} 00^{\prime} 530^{\prime \prime}$ & 630 & 642 & 4 \\
\hline 2004 & WDFW & Presidents Channel & $10 / 9 / 2004$ & $48^{\circ} 37^{\prime} 698^{\prime \prime}$ & $123^{\circ} 05^{\prime} 055^{\prime \prime}$ & 684 & 792 & 1 \\
\hline 2004 & WDFW & Presidents Channel & $10 / 9 / 2004$ & $48^{\circ} 40^{\prime} 892^{\prime \prime}$ & $123^{\circ} 00^{\prime} 785^{\prime \prime}$ & 468 & 540 & 0 \\
\hline 2004 & WDFW & Presidents Channel & $10 / 9 / 2004$ & $48^{\circ} 37^{\prime} 602^{\prime \prime}$ & $123^{\circ} 05^{\prime} 143^{\prime \prime}$ & 768 & 810 & 6 \\
\hline 2004 & WDFW & Presidents Channel & $10 / 9 / 2004$ & $48^{\circ} 40^{\prime} 842^{\prime \prime}$ & $123^{\circ} 00^{\prime} 842^{\prime \prime}$ & 462 & 480 & 3 \\
\hline 2005 & WDFW & Colvos Passage & $1 / 20 / 2005$ & $47^{\circ} 21^{\prime} 507^{\prime \prime}$ & $122^{\circ} 31^{\prime} 907^{\prime \prime}$ & 204 & 288 & 0 \\
\hline 2005 & WDFW & Piner Point & $1 / 21 / 2005$ & $47^{\circ} 21^{\prime} 792^{\prime \prime}$ & $122^{\circ} 25.676^{\prime \prime}$ & 552 & 582 & 2 \\
\hline 2005 & WDFW & S. Piner Point & $1 / 21 / 2005$ & $47^{\circ} 20^{\prime} 295^{\prime \prime}$ & $122^{\circ} 28^{\prime} 395^{\prime \prime}$ & 144 & 168 & 0 \\
\hline 2005 & WDFW & S. Piner Point & $1 / 21 / 2005$ & $47^{\circ} 20^{\prime} 074^{\prime \prime}$ & $122^{\circ} 27^{\prime} 798^{\prime \prime}$ & 150 & 210 & 0 \\
\hline 2005 & WDFW & S. Piner Point & $1 / 21 / 2005$ & $47^{\circ} 20^{\prime} 233^{\prime \prime}$ & $122^{\circ} 28^{\prime} 503^{\prime \prime}$ & 168 & 216 & 0 \\
\hline 2005 & WDFW & Les Davis Pier & $1 / 21 / 2005$ & $47^{\circ} 16^{\prime} 848^{\prime \prime}$ & $122^{\circ} 28^{\prime} 048^{\prime \prime}$ & 114 & 162 & 1 \\
\hline 2005 & WDFW & Les Davis Pier & $1 / 22 / 2005$ & $47^{\circ} 17^{\prime} 508^{\prime \prime}$ & $122^{\circ} 28^{\prime} 905^{\prime \prime}$ & 480 & 522 & 1 \\
\hline 2005 & WDFW & Three Tree Point & $1 / 22 / 2005$ & $47^{\circ} 27^{\prime} 967^{\prime \prime}$ & $122^{\circ} 23^{\prime} 313^{\prime \prime}$ & 576 & 708 & 6 \\
\hline 2005 & WDFW & Point Beal & $1 / 22 / 2005$ & $47^{\circ} 24^{\prime} 05^{\prime \prime}$ & $122^{\circ} 24^{\prime} 448^{\prime \prime}$ & 540 & 576 & 1 \\
\hline 2005 & WDFW & Colvos Passage & $3 / 31 / 2005$ & $47^{\circ} 21^{\prime} 146^{\prime \prime}$ & $122^{\circ} 32^{\prime} 240^{\prime \prime}$ & 276 & 312 & 0 \\
\hline 2005 & WDFW & Point Robinson & $4 / 1 / 2005$ & $47^{\circ} 21^{\prime} 724^{\prime \prime}$ & $122^{\circ} 25^{\prime} 782^{\prime \prime}$ & 552 & 588 & 0 \\
\hline 2005 & WDFW & Les Davis Pier & $4 / 1 / 2005$ & $47^{\circ} 17^{\prime} 185^{\prime \prime}$ & $122^{\circ} 28^{\prime} 237^{\prime \prime}$ & 462 & 498 & 0 \\
\hline 2005 & WDFW & Les Davis Pier & $4 / 1 / 2005$ & $47^{\circ} 16^{\prime} 824^{\prime \prime}$ & $122^{\circ} 28^{\prime} 088^{\prime \prime}$ & 108 & 156 & 0 \\
\hline 2005 & WDFW & Quartermaster Harbor & $4 / 2 / 2005$ & $47^{\circ} 22^{\prime} 987^{\prime \prime}$ & $122^{\circ} 27^{\prime} 894^{\prime \prime}$ & 42 & 42 & 0 \\
\hline 2005 & WDFW & Quartermaster Harbor & $4 / 2 / 2005$ & $47^{\circ} 21^{\prime} 979^{\prime \prime}$ & $122^{\circ} 28^{\prime} 927^{\prime \prime}$ & 60 & 66 & 0 \\
\hline 2005 & WDFW & Three Tree Point & $4 / 2 / 2005$ & $47^{\circ} 28^{\prime} 131^{\prime \prime}$ & $122^{\circ} 22^{\prime} 898^{\prime \prime}$ & 294 & 696 & 0 \\
\hline 2005 & WDFW & Elliot Bay & $6 / 21 / 2005$ & $47^{\circ} 37^{\prime} 391^{\prime \prime}$ & $122^{\circ} 27^{\prime} 263^{\prime \prime}$ & 570 & 588 & 1 \\
\hline 2005 & WDFW & Elliot Bay & $6 / 22 / 2005$ & $47^{\circ} 37^{\prime} 311^{\prime \prime}$ & $122^{\circ} 25^{\prime} 488^{\prime \prime}$ & 552 & 564 & 1 \\
\hline 2005 & WDFW & Alki Beach & $6 / 22 / 2005$ & $47^{\circ} 35^{\prime} 292^{\prime \prime}$ & $122^{\circ} 24^{\prime} 669^{\prime \prime}$ & 318 & 402 & 2 \\
\hline
\end{tabular}


Table 4 continued

\begin{tabular}{|c|c|c|c|c|c|c|c|c|}
\hline Year & Agency & Area fished & $\begin{array}{l}\text { Date gear } \\
\text { set }\end{array}$ & Latitude & Longitude & $\begin{array}{l}\text { Min } \\
\text { depth (ft) }\end{array}$ & $\begin{array}{l}\text { Max } \\
\text { depth (ft) }\end{array}$ & $\begin{array}{l}\text { Total sixgill } \\
\text { caught }\end{array}$ \\
\hline 2005 & WDFW & Colvos Passage & $6 / 23 / 2005$ & $47^{\circ} 21^{\prime} 164^{\prime \prime}$ & $122^{\circ} 32^{\prime} 124^{\prime \prime}$ & 222 & 306 & 2 \\
\hline 2005 & WDFW & Piner Point & $6 / 23 / 2005$ & $47^{\circ} 21^{\prime} 663^{\prime \prime}$ & $122^{\circ} 25^{\prime} 545^{\prime \prime}$ & 552 & 570 & 4 \\
\hline 2005 & WDFW & Les Davis Pier & $6 / 23 / 2005$ & $47^{\circ} 17^{\prime} 603^{\prime \prime}$ & $122^{\circ} 28^{\prime} 717^{\prime \prime}$ & 504 & 504 & 12 \\
\hline 2005 & WDFW & Blake Island & $6 / 24 / 2005$ & $47^{\circ} 32^{\prime} 541^{\prime \prime}$ & $122^{\circ} 30^{\prime} 979^{\prime \prime}$ & 384 & 396 & 7 \\
\hline 2005 & WDFW & Yukon Harbor & $6 / 24 / 2005$ & $47^{\circ} 31^{\prime} 926^{\prime \prime}$ & $122^{\circ} 31^{\prime} 284^{\prime \prime}$ & 126 & 168 & 1 \\
\hline 2005 & WDFW & Duwamish Head & $11 / 15 / 2005$ & $47^{\circ} 35^{\prime} 763^{\prime \prime}$ & $122^{\circ} 22^{\prime} 846^{\prime \prime}$ & 186 & 222 & 0 \\
\hline 2005 & WDFW & Myrtle Edwards Park & $11 / 15 / 2005$ & $47^{\circ} 37^{\prime} 988^{\prime \prime}$ & $122^{\circ} 22^{\prime} 996^{\prime \prime}$ & 156 & 204 & 0 \\
\hline 2005 & WDFW & Duwamish River & $11 / 15 / 2005$ & $47^{\circ} 35^{\prime} 260^{\prime \prime}$ & $122^{\circ} 22^{\prime} 542^{\prime \prime}$ & 120 & 150 & 0 \\
\hline 2005 & WDFW & Fauntleroy & $11 / 16 / 2005$ & $47^{\circ} 30^{\prime} 040^{\prime \prime}$ & $122^{\circ} 23^{\prime} 520^{\prime \prime}$ & 300 & 372 & 0 \\
\hline 2005 & WDFW & Seahurst/Three Tree & $11 / 16 / 2005$ & $47^{\circ} 28^{\prime} 104^{\prime \prime}$ & $122^{\circ} 22^{\prime} 396^{\prime \prime}$ & 600 & 654 & 12 \\
\hline 2005 & WDFW & Point Beal & $11 / 16 / 2005$ & $47^{\circ} 29^{\prime} 464^{\prime \prime}$ & $122^{\circ} 27^{\prime} 074^{\prime \prime}$ & 252 & 336 & 1 \\
\hline 2006 & NOAA & Elliot Bay Deep & $5 / 4 / 2006$ & $47^{\circ} 35^{\prime} 286^{\prime \prime}$ & $122^{\circ} 22^{\prime} 300^{\prime \prime}$ & 240 & 250 & 2 \\
\hline 2006 & NOAA & Elliot Bay & $5 / 4 / 2006$ & $47^{\circ} 35^{\prime} 432^{\prime \prime}$ & $122^{\circ} 22^{\prime} 678^{\prime \prime}$ & 140 & 145 & 6 \\
\hline 2006 & NOAA & Elliot Bay & $5 / 5 / 2006$ & $47^{\circ} 35^{\prime} 437^{\prime \prime}$ & $122^{\circ} 22^{\prime} 267^{\prime \prime}$ & 197 & 247 & 1 \\
\hline 2006 & WDFW & Boundary Pass & $5 / 9 / 2006$ & $48^{\circ} 43^{\prime} 004^{\prime \prime}$ & $123^{\circ} 09^{\prime} 087^{\prime \prime}$ & 600 & 600 & 0 \\
\hline 2006 & WDFW & North of Stewart Island & $5 / 9 / 2006$ & $48^{\circ} 40^{\prime} 080^{\prime \prime}$ & $123^{\circ} 08^{\prime} 088^{\prime \prime}$ & 240 & 276 & 0 \\
\hline 2006 & WDFW & North of Stewart Island (shallow) & $5 / 9 / 2006$ & $48^{\circ} 42^{\prime} 012^{\prime \prime}$ & $123^{\circ} 09^{\prime} 014^{\prime \prime}$ & 360 & 420 & 0 \\
\hline 2006 & WDFW & Deep Presidents Channel & $5 / 10 / 2006$ & $48^{\circ} 40^{\prime} 868^{\prime \prime}$ & $123^{\circ} 00^{\prime} 071^{\prime \prime}$ & 606 & 624 & 0 \\
\hline 2006 & WDFW & Cowlitz Bay & $5 / 10 / 2006$ & $48^{\circ} 40^{\prime} 750^{\prime \prime}$ & $123^{\circ} 04^{\prime} 529^{\prime \prime}$ & 216 & 216 & 0 \\
\hline 2006 & WDFW & Point Disney Presidents Channel & $5 / 10 / 2006$ & $48^{\circ} 40^{\prime} 323^{\prime \prime}$ & $123^{\circ} 02^{\prime} 385^{\prime \prime}$ & 360 & 360 & 0 \\
\hline 2006 & WDFW & Flat top Island & $5 / 10 / 2006$ & $48^{\circ} 39^{\prime} 106^{\prime \prime}$ & $123^{\circ} 03^{\prime} 969^{\prime \prime}$ & 564 & 600 & 0 \\
\hline 2007 & NOAA & Elliott Bay & $1 / 21 / 2007$ & $47^{\circ} 35^{\prime} 502^{\prime \prime}$ & $122^{\circ} 22^{\prime} 702^{\prime \prime}$ & 250 & 250 & 1 \\
\hline 2007 & NOAA & Elliott Bay & $1 / 21 / 2007$ & $47^{\circ} 35^{\prime} 382^{\prime \prime}$ & $122^{\circ} 22^{\prime} 470^{\prime \prime}$ & 200 & 215 & 0 \\
\hline 2007 & NOAA & Elliott Bay & $1 / 21 / 2007$ & $47^{\circ} 35^{\prime} 911^{\prime \prime}$ & $122^{\circ} 22^{\prime} 955^{\prime \prime}$ & 180 & 200 & 0 \\
\hline 2007 & NOAA & Three Tree Point & $1 / 21 / 2007$ & $47^{\circ} 28^{\prime} 007^{\prime \prime}$ & $122^{\circ} 22^{\prime} 722^{\prime \prime}$ & 218 & 236 & 0 \\
\hline 2007 & NOAA & Three Tree Point & $1 / 21 / 2007$ & $47^{\circ} 28^{\prime} 455^{\prime \prime}$ & $122^{\circ} 22^{\prime} 411^{\prime \prime}$ & 202 & 216 & 0 \\
\hline 2007 & NOAA & Three Tree Point & $1 / 21 / 2007$ & $47^{\circ} 26^{\prime} 798^{\prime \prime}$ & $122^{\circ} 22^{\prime} 846^{\prime \prime}$ & 225 & 255 & 0 \\
\hline 2007 & NOAA & S. Bainbridge & $1 / 24 / 2007$ & $47^{\circ} 34^{\prime} 555^{\prime \prime}$ & $122^{\circ} 28^{\prime} 409^{\prime \prime}$ & 190 & 450 & 0 \\
\hline 2007 & NOAA & S. Bainbridge & $1 / 24 / 2007$ & $47^{\circ} 35^{\prime} 606^{\prime \prime}$ & $122^{\circ} 28^{\prime} 489^{\prime \prime}$ & 200 & 280 & 0 \\
\hline 2007 & NOAA & S. Bainbridge & $1 / 24 / 2007$ & $47^{\circ} 33^{\prime} 649^{\prime \prime}$ & $122^{\circ} 29^{\prime} 454^{\prime \prime}$ & 250 & 285 & 0 \\
\hline 2007 & NOAA & S. Bainbridge & $1 / 24 / 2007$ & $47^{\circ} 35^{\prime} 341^{\prime \prime}$ & $122^{\circ} 22^{\prime} 375^{\prime \prime}$ & 200 & 250 & 0 \\
\hline 2007 & NOAA & Elliott Bay & $3 / 20 / 2007$ & $47^{\circ} 35^{\prime} 636^{\prime \prime}$ & $122^{\circ} 22^{\prime} 554^{\prime \prime}$ & 270 & 270 & 0 \\
\hline 2007 & NOAA & Elliott Bay & $3 / 20 / 2007$ & $47^{\circ} 35^{\prime} 196^{\prime \prime}$ & $122^{\circ} 22^{\prime} 485^{\prime \prime}$ & 70 & 70 & 1 \\
\hline 2007 & NOAA & Elliott Bay & $3 / 20 / 2007$ & $47^{\circ} 35^{\prime} 471^{\prime \prime}$ & $122^{\circ} 22^{\prime} 827^{\prime \prime}$ & 65 & 65 & 0 \\
\hline 2007 & NOAA & Elliott Bay & $3 / 20 / 2007$ & $47^{\circ} 35^{\prime} 994^{\prime \prime}$ & $122^{\circ} 22^{\prime} 992^{\prime \prime}$ & 240 & 240 & 1 \\
\hline 2007 & NOAA & Elliott Bay & $3 / 20 / 2007$ & $47^{\circ} 35^{\prime} 149^{\prime \prime}$ & $122^{\circ} 22^{\prime} 093^{\prime \prime}$ & 55 & 55 & 0 \\
\hline 2007 & NOAA & Elliott Bay & $3 / 20 / 2007$ & $47^{\circ} 35^{\prime} 191^{\prime \prime}$ & $122^{\circ} 22^{\prime} 449^{\prime \prime}$ & 160 & 160 & 4 \\
\hline 2007 & NOAA & Elliott Bay & $3 / 20 / 2007$ & $47^{\circ} 35^{\prime} 636^{\prime \prime}$ & $122^{\circ} 22^{\prime} 554^{\prime \prime}$ & 280 & 280 & 0 \\
\hline 2007 & NOAA & Elliott Bay & $3 / 20 / 2007$ & $47^{\circ} 35^{\prime} 127^{\prime \prime}$ & $122^{\circ} 22^{\prime} 407^{\prime \prime}$ & 80 & 100 & 0 \\
\hline 2007 & NOAA & Elliott Bay & $3 / 20 / 2007$ & $47^{\circ} 35^{\prime} 131^{\prime \prime}$ & $122^{\circ} 22^{\prime} 130^{\prime \prime}$ & 70 & 55 & 5 \\
\hline 2007 & NOAA & Elliott Bay & $3 / 20 / 2007$ & $47^{\circ} 35^{\prime} 313^{\prime \prime}$ & $122^{\circ} 22^{\prime} 267^{\prime \prime}$ & 210 & 215 & 1 \\
\hline 2007 & NOAA & Elliott Bay & $3 / 22 / 2007$ & $47^{\circ} 35^{\prime} 797^{\prime \prime}$ & $122^{\circ} 23^{\prime} 057^{\prime \prime}$ & 60 & 60 & 0 \\
\hline 2007 & NOAA & Elliott Bay & $3 / 22 / 2007$ & $47^{\circ} 35^{\prime} 835^{\prime \prime}$ & $122^{\circ} 22^{\prime} 696^{\prime \prime}$ & 300 & 305 & 0 \\
\hline 2007 & NOAA & Elliott Bay & $3 / 22 / 2007$ & $47^{\circ} 36^{\prime} 939^{\prime \prime}$ & $122^{\circ} 22^{\prime} 773^{\prime \prime}$ & 380 & 390 & 0 \\
\hline 2007 & NOAA & Elliott Bay & $3 / 22 / 2007$ & $47^{\circ} 37^{\prime} 238^{\prime \prime}$ & $122^{\circ} 21^{\prime} 954^{\prime \prime}$ & 65 & 75 & 0 \\
\hline 2007 & NOAA & Elliott Bay & $3 / 22 / 2007$ & $47^{\circ} 37^{\prime} 012^{\prime \prime}$ & $122^{\circ} 21^{\prime} 650^{\prime \prime}$ & 50 & 50 & 0 \\
\hline 2007 & NOAA & Elliott Bay & $3 / 22 / 2007$ & $47^{\circ} 36^{\prime} 700^{\prime \prime}$ & $122^{\circ} 21^{\prime} 952^{\prime \prime}$ & 280 & 285 & 1 \\
\hline 2007 & NOAA & Elliott Bay & $3 / 22 / 2007$ & $47^{\circ} 35^{\prime} 807^{\prime \prime}$ & $122^{\circ} 23^{\prime} 070^{\prime \prime}$ & 50 & 55 & 0 \\
\hline
\end{tabular}


Table 4 continued

\begin{tabular}{llllllrrr}
\hline Year & Agency & Area fished & $\begin{array}{l}\text { Date gear } \\
\text { set }\end{array}$ & Latitude & Longitude & $\begin{array}{l}\text { Min } \\
\text { depth (ft) }\end{array}$ & $\begin{array}{l}\text { Max } \\
\text { depth (ft) }\end{array}$ & $\begin{array}{l}\text { Total sixgill } \\
\text { caught }\end{array}$ \\
\hline 2007 & NOAA & Elliott Bay & $3 / 22 / 2007$ & $47^{\circ} 35^{\prime} 727^{\prime \prime}$ & $122^{\circ} 22^{\prime} 585^{\prime \prime}$ & 300 & 300 & 0 \\
2007 & NOAA & Elliott Bay & $3 / 22 / 2007$ & $47^{\circ} 36^{\prime} 953^{\prime \prime}$ & $122^{\circ} 21^{\prime} 544^{\prime \prime}$ & 55 & 60 & 0 \\
2007 & NOAA & Elliott Bay & $3 / 22 / 2007$ & $47^{\circ} 36^{\prime} 620^{\prime \prime}$ & $122^{\circ} 21^{\prime} 761^{\prime \prime}$ & 285 & 290 & 0 \\
2007 & NOAA & Elliott Bay & $4 / 16 / 2007$ & $47^{\circ} 35^{\prime} 166^{\prime \prime}$ & $122^{\circ} 22^{\prime} 471^{\prime \prime}$ & 60 & 80 & 0 \\
2007 & NOAA & Elliott Bay & $4 / 16 / 2007$ & $47^{\circ} 35^{\prime} 541^{\prime \prime}$ & $122^{\circ} 22^{\prime} 548^{\prime \prime}$ & 270 & 280 & 3 \\
2007 & NOAA & Elliott Bay & $4 / 16 / 2007$ & $47^{\circ} 35^{\prime} 123^{\prime \prime}$ & $122^{\circ} 22^{\prime} 147^{\prime \prime}$ & 50 & 50 & 1 \\
2007 & NOAA & Elliott Bay & $4 / 16 / 2007$ & $47^{\circ} 35^{\prime} 349^{\prime \prime}$ & $122^{\circ} 22^{\prime} 321^{\prime \prime}$ & 220 & 230 & 2 \\
2007 & NOAA & Elliott Bay & $4 / 17 / 2007$ & $47^{\circ} 35^{\prime} 558^{\prime \prime}$ & $122^{\circ} 22^{\prime} 464^{\prime \prime}$ & 280 & 280 & 0 \\
2007 & NOAA & Elliott Bay & $4 / 17 / 2007$ & $47^{\circ} 35^{\prime} 141^{\prime \prime}$ & $122^{\circ} 22^{\prime} 447^{\prime \prime}$ & 55 & 80 & 0 \\
2007 & NOAA & Elliott Bay & $4 / 17 / 2007$ & $47^{\circ} 35^{\prime} 144^{\prime \prime}$ & $122^{\circ} 22^{\prime} 129^{\prime \prime}$ & 50 & 55 \\
2007 & NOAA & Elliott Bay & $4 / 17 / 2007$ & $47^{\circ} 35^{\prime} 367^{\prime \prime}$ & $122^{\circ} 22^{\prime} 346^{\prime \prime}$ & 210 & 225 \\
\hline
\end{tabular}

\section{References}

Ahonen H, Harcourt RG, Stow AJ (2009) Nuclear and mitochondrial DNA reveals isolation of imperiled grey nurse shark populations (Carcharias taurus). Mol Ecol 18:4409-4421

Andrews KS, Levin PS, Katz SL (2007) Acoustic monitoring of sixgill shark movements in Puget Sound: evidence for localized movement. Can J Zool 85:1136-1142

Andrews KS, Williams GD, Farrer D, Tolimieri N, Harvey CJ, Bargmann G, Levin PS (2009) Diel activity patterns of sixgill sharks Hexanchus griseus: the ups-and-downs of an apex predator. Anim Behav 78:525-536

Andrews KS, Williams GD, Levin PS (2010) Seasonal and ontogenetic changes in movement patterns of sixgill sharks. PLoS One 5(9):e12549

Baum JK, Myers RA (2004) Shifting baselines and the decline of pelagic sharks in the Gulf of Mexico. Ecol Lett 7:135-145

Baum JK, Myers RA, Kehler DG, Worm B, Harley SJ, Doherty PA (2003) Collapse and conservation of shark populations in the Northwest Atlantic. Science 299:389-392

Buston PM, Fauvelot C, Wong MYL, Planes S (2009) Genetic relatedness in groups of the humbug damselfish Dascyllus aruanus: small, similar-sized individuals may be close kin. Mol Ecol 18(22):4707-4715

Capapé C, Hemida F, Guélorget O, Barrull J, Mate I, Ben Souissi J, Bradaï MN (2004) Reproductive biology of the Bluntnose sixgill shark Hexanchus griseus (Bonnaterre, 1788) (Chondrichthyes: Hexanchidae) from the Mediterranean Sea: a review. Acta Adriat 45(1):95-106

Carey FG, Clark E (1995) Depth telemetry from the sixgill shark, Hexanchus griseus, at Bermuda. Env Biol Fishes 42(1):7-14

Castro JI (1983) The sharks of North American waters. Texas A\&M University Press, College Station

Chapman DD, Prodohl PA, Gelsleicher J, Manire CA, Mahmood SS (2004) Predominance of genetic monogamy by females in a hammerhead shark, Sphyrna tiburo: implications for shark conservation. Mol Ecol 13:1965-1974

Cornuet JM, Luikart G (1997) Description and power analysis of two tests for detecting recent population bottlenecks from allele frequency data. Genetics 144:2001-2014

Daly-Engel TS, Grubbs RD, Bowen BW, Toonen RJ (2007) Frequency of multiple paternity in an unexploited tropical population of sandbar shark. Can J Fish Aquat Sci 64:198-204

Daly-Engel TS, Grubbs RD, Feldheim KA, Bowen BW, Toonen RJ (2010) Is multiple mating beneficial or unavoidable? Low multiple paternity and genetic diversity in the shortspine spurdog Squalus mitsukurii. Mar Eco Prog Ser 403:255-267

DiBattista JD, Feldheim KA, Gruber SH, Hendry AP (2008) Are indirect genetic benefits associated with polyandry? Testing predictions in a natural population of lemon sharks. Mol Ecol 17:783-795

Dunbrack R, Zielinski R (2003) Seasonal and diurnal activity of sixgill sharks (Hexanchus griseus) on a shallow water reef in the Strait of Georgia, British Columbia. Can J Zool 81:1107-1111

Ebert DA (2002) Some observations on the reproductive biology of the sixgill shark, Hexanchus griseus (Bonnaterre, 1788) from southern African waters. S Afr J Mar Sci 24:359-363

Ebert DA (2003) The sharks, rays and chimaeras of California. University of California Press, San Francisco

Ellis R (1983) The book of sharks. Alfred A. Knopf Inc, New York

Feldheim KA, Gruber SH, Ashley MV (2001) Population genetics structure of the lemon shark (Negaprion brevirostris) in the western Atlantic: DNA microsatellite variation. Mol Ecol 10:295-303

Feldheim KA, Gruber SH, Ashley MV (2002) The breeding biology of lemon sharks at a tropical nursery lagoon. Proc R Soc Lond B 269:1655-1661

Frankham R (1996) Relationship of genetic variation to population size in wildlife. Conserv Biol 10(6):1500-1508

Goudet J (1995) FSTAT (version 1.2): a computer program to calculate $F$-statistics. J Hered 86:485-486

Griffin AS, West SA (2003) Kin discrimination and the benefit of helping in cooperatively breeding vertebrates. Science 302:634-636

Hamilton WD (1963) The evolution of altruistic behavior. Am Nat 97:354-356

Hamilton WD (1964) The genetical evolution of social behaviour, I and II. J Theor Biol 7:1-52

Heist EJ, Gold JR (1999) Microsatellite DNA variation in sandbar sharks (Carcharhinus plumbeus) from the Gulf of Mexico and Mid-Atlantic Bight. Copeia 1:182-186

Heist EJ, Jenkot JL, Keeney DB, Lane RL, Moyer GR, Reading BJ, Smith NL (2003) Isolation and characterization of polymorphic microsatellite loci in nurse shark (Ginglymostoma cirratum). Mol Ecol Notes 3:59-61

Hoelze AR, Shivji MS, Magnussen J, Francis MP (2006) Low worldwide genetic diversity in the basking shark (Cetorhinus maximus). Biol Lett 2:639-642. doi:10.1098/rsbl.2006.0513

Hoenig JM, Gruber SH (1990) Life-history patterns in the elasmobranchs: implications for fisheries management. In: Pratt HL Jr, 
Gruber SH, Taniuchi T (eds) Elasmobranchs as living resources: advances in biology, ecology, systematics and status of the fisheries. NOAA Tech. Rep. NMFS vol 90, pp 1-16

IUCN (2008) http://www.iucn.redlist.org. Accessed Dec 2008

Jones AG (2005) GERUD 2.0: a computer program for the reconstruction of paternal genotypes from half sib-progeny arrays with known or unknown parents. Mol Ecol Notes 5:708-711

Kalinowski ST, Wagner AP, Taper ML (2006) ML-Relate: a computer program for maximum likelihood estimation of relatedness and relationship. Mol Ecol Notes 6:576-579

Karl SA (2008) The effect of multiple paternity on the genetically effective size of a population. Mol Ecol 17(18):3973-3977

Keeney DB, Heupel MR, Hueter RE, Heist EJ (2005) Microsatellite and mitochondrial DNA analyses of the genetic structure of blacktip shark (Carcharhinus limbatus) nurseries in the northwestern Atlantic, Gulf of Mexico, and Caribbean Sea. Mol Ecol 14(7):1911-1923

Keller LF, Waller DM (2002) Inbreeding effects in wild populations. Trends Ecol Evol 17:230-241

Kinney MJ, Simpfendorfer CA (2009) Reassessing the value of nursery areas to shark conservation and management. Conserv Lett 2:53-60

Kohler NE, Turner PA (2001) Shark tagging: a review of conventional methods and studies. Environ Bio Fish 60:191-223

Konovalov DA, Manning C, Henshaw MT (2004) KINGROUP: a program for pedigree relationship reconstruction and kin group assignments using genetic markers. Mol Ecol Notes 4:779-782

Larson S, Tinnemore D, Amemiya C (2009) Microsatellite loci within sixgill sharks, Hexanchus griseus. Mol Ecol Res 9(3):978-981

Martin AP, Naylor GJP, Palumbi SR (1992) Rates of mtDNA evolution in sharks are slow compared to humans. Nature 357:153-155

Miller-Sims VC, Gerlach G, Kingsford MJ, Atema J (2008) Dispersal in the spiny damselfish, Acanthochromis polyacanthus, a coral reef fish species without a larval pelagic stage. Mol Ecol 17:5036-5048

Musick JA, Harbin MM, Berkeley SA, Burgess GH, Eklund AM, Findley L, Gilmore RG, Golden JT, Ha DS, Huntsman GR, McGovern JC, Parker SJ, Poss SG, Sala E, Schmidt TW, Sedberry GR, Weeks H, Wright SG (2000) Marine, estuarine, and diadromous fish stocks at risk of extinction in North America (exclusive of Pacific salmonids). Fisheries 25(11):6-30

Neff BD, Pitcher TE, Repka J (2002) A Bayesian model for assessing the frequency of multiple mating. J Hered 93:406-414

Olsén KH, Petersson E, Ragnarsson B, Lundqvist H, Järvi T (2004) Downstream migration in Atlantic salmon (Salmo salar) smolt sibling groups. Can J Fish Aquat Sci 61(3):328-331

Pardini AT, Jones CS, Scholl MC, Noble LR (2000) Isolation and characterization of dinucleotide microsatellite loci in the Great
White Shark, Carcharodon carcharias. Mol Ecol 9(8):1176-1178

Planes S, Bonhomme F, Galzin R (1993) Genetic structure of Dascyllus aruanus populations in French Polynesia. Mar Biol 117:665-674

Portnoy DS, Piercy AN, Musick JA, Burgess GH, Graves JE (2007) Genetic polyandry and sexual conflict in the sandbar shark, Carcharhinus plumbeus, in the western North Atlantic and Gulf of Mexico. Mol Ecol 16:187-197

Pritchard JK, Stephens M, Donnelly P (2000) Inference of population structure using multilocus genotype data. Genetics 155:945-959

Raymond M, Roussett F (1995) Genepop (Version 1.2): population genetics software for exact tests and ecumenicism. J Hered $86: 248-249$

Rice WR (1989) Analyzing tables of statistical tests. Evolution 43:223-225

Rozen S, Skaletsky HJ (2000) Primer3 on the WWW for general users and for biologist programmers. In: Krawetz S, Misener S (eds) Bioinformatics methods and protocols: methods in molecular biology. Humana Press, Totowa, pp 365-386

Rupp J (2001) A natural history of the sixgill shark, Hexanchus griseus. Proc Puget Sound Res 2001—the Fifth Puget Sound Research Conference

Schindler DE, Essington TE, Kitchell JF, Boggs C, Hilborn R (2002) Sharks and tunas: fisheries impacts on predators with contrasting life histories. Ecol Appl 12(3):735-748

Schmidt JV, Schmidt CL, Ozer F, Ernst RE, Feldheim KA et al (2009) Low genetic differentiation across three major ocean populations of the whale shark, Rhincodon typus. PLoS One 4(4):e4988. doi:10.1371/journal.pone.0004988

Selkoe KA, Gaines SD, Caselle JE, Warner RR (2006) Current shifts and kin aggregation explain genetic patchiness in fish recruits. Ecology 87:3082-3094

Sikkel PC, Fuller CA (2010) Shoaling preference and evidence for maintenance of sibling groups by juvenile black perch (Embiotoca jacksoni). J Fish Biol 76:1671-1681

Simpfendorfer CA (1999) Demographic analysis of the dusky shark fishery in southwestern Australia. In: Musick JA (ed) Life in the slow lane: ecology and conservation of long lived marine animals. American Fisheries Society Symposium 23. Bethesda, pp $149-160$

Wang J (2004) Sibship reconstruction from genetic data with typing errors. Genetics 166:1963-1979

Whitney NM, Pratt HL, Carrier JC (2004) Group courtship, mating behavior and siphon sac function in the whitetip reef shark, Triaenodon obesus. Anim Behav 68:1435-1442

Williams GD, Andrews KS, Farrer D, Levin PS (2010) Catch rates and population demographics of bluntnose sixgill sharks. Trans Am Fish Soc 139:108-116 